\title{
Observations on the resistance to drying of staphylococcal strains
}

\author{
MARY A. BEARD-PEGLER, ELIZABETH STUBBS and ALISON M. VICKERY*
}

\begin{abstract}
Department of Infectious Diseases, The University of Sydney, Sydney NSW 2006 and Department of Microbiology, Fairfax Institute of Pathology, Royal Prince Alfred Hospital, Sydney, NSW 2050, Australia
\end{abstract}

\begin{abstract}
Summary. Death rates have been determined for staphylococcal strains dried on cotton blanket material and stored at room temperature in the dark and in the light. Methicillin-resistant Staphylococcus aureus (MRSA) strains that produced a golden pigment and had a wide distribution within the hospital survived for longer periods than MRSA strains that produced little pigment and had a restricted local distribution. Death rates of methicillin-sensitive strains of $S$. aureus at day 7 were similar to those of the general epidemic MRSA strains, and there was no significant difference between the death rates at day 7 of the local epidemic MRSA strains and the coagulase-negative strains.
\end{abstract}

\section{Introduction}

Strains of staphylococci can survive for varying periods in samples of dust. Lidwell and Lowbury (1950) reported that the daily death rate of strains of Staphylococcus aureus varied with the relative humidity. Rountree (1963) studied the survival of staphylococci on various textiles in common use in hospitals and showed that some epidemic strains of $S$. aureus belonging to group-I phage-typing patterns survived for longer on cotton lint than nonepidemic strains with group-II phage-typing patterns. She also observed that cultures dried on pieces of woollen blanket survived for a longer time than when they were dried on cotton. It has been reported that the survival of staphylococci dried on glass was associated with pigment production and it was also noted that there was no difference in the survival rate of strains of pigmented methicillinresistant $S$. aureus (MRSA) when compared with the survival rates of pigmented methicillin-sensitive staphylococci after drying for $5 \mathrm{~h}$ (Lacey and Grinsted, 1973).

Since 1981, strains of MRSA causing severe infections have been isolated from hospital patients in many countries including Australia (McDonald et al., 1981), Ireland (Cafferkey et al., 1983), England (Bradley et al., 1985) and the USA (Schaefler et al., 1981). In Royal Prince Alfred Hospital (RPAH) five prevalent strains of MRSA have been identified by phage typing over this period (Vickery et al., 1983, 1986). Epidemiological

Received 19 Sep. 1987; revised version accepted 2 Nov. 1987. studies have shown that strains of two of these phage-typing patterns have been consistently isolated from general epidemics in many wards in RPAH and from several other hospitals in Sydney and NSW (Vickery and Beard-Pegler, 1986).

Strains belonging to the three other phage-typing patterns have been isolated from individual outbreaks in some hospitals but not in others and have also been restricted to specific areas in RPAH. Their distribution would appear, therefore, to be localised, in contrast to the wide-spread distribution of the other MRSA strains.

To investigate why MRSA strains vary in their ability to survive and spread in the ward environment, their resistance to drying on a cotton-blanket material was studied. The survival rates of various MRSA strains were compared with each other, with strains of methicillin-sensitive $S$. aureus and with strains of coagulase-negative staphylococci (CNS).

\section{Materials and methods}

\section{Strains of staphylococci}

The strains of $S$. aureus examined included 16 methicillin-resistant and nine methicillin-sensitive isolates from RPAH. The strains were selected to include several representative examples of each of the major phage-typing patterns identified since 1980 (Vickery et al., 1983, 1986). Twelve strains of CNS, recently isolated at RPAH and identified by the API Staph system, were also studied. These strains were isolated from blood cultures and cerebrospinal fluid (CSF) infections and were considered clinically significant on the basis of the 
following criteria: isolates from blood cultures were regarded as significant if a CNS was isolated from sequential blood cultures from a febrile patient with an intravenous line (peripheral or central) or another vascular prosthetic device such as a prosthetic heart valve; $\mathrm{CNS}$ isolates from CSF specimens were regarded as significant if the patient had a CSF shunt, a fever and a raised CSF neutrophil count. All strains were stored on nutrient-agar slopes at room temperature. Media, antibiotic-sensitivity-testing and phage-typing methods have been described previously (Vickery et al., 1983).

\section{Drying}

The method of drying and the calculation of the death rates were those used by Rountree (1963). The strain to be dried was inoculated into broth from an overnight culture and grown at $37^{\circ} \mathrm{C}$ for $4 \mathrm{~h}$. Between 10 and 20 squares of cotton-blanket material, $20 \mathrm{~mm} \times 20 \mathrm{~mm}$, were placed in glass petri dishes, inoculated with $0.1 \mathrm{ml}$ of the test strain, and placed either in a dark cupboard or on an open shelf in a laboratory that had good natural lighting. Temperature and humidity were not controlled but readings were taken daily and the temperature ranged from $22^{\circ} \mathrm{C}$ to $29^{\circ} \mathrm{C}$, with a relative humidity of $50-67 \%$ for the period of the study.

\section{Counting}

Counts were calculated by placing a square of textile in $5 \mathrm{ml}$ of broth which was then vortex mixed for $1 \mathrm{~min}$ and ten-fold dilutions were made; $0 \cdot 1-\mathrm{ml}$ samples were placed on to quadrants of blood-agar plates, spread with a sterile glass rod and incubated overnight at $37^{\circ} \mathrm{C}$.

\section{Death rates}

$\mathrm{K}$, the death rate per day, was calculated as follows (Rountree, 1963):

$$
\mathrm{K}=2 \cdot 3 \times \frac{\mathrm{B}_{0}-\mathrm{B}_{\mathrm{t}}}{\mathrm{t}}
$$

when $t=$ time of drying in days, $B_{0}=\log _{10}$ count at time $0, B_{t}=\log _{10}$ count at time $t$.

\section{Pigment}

All strains were tested for pigment production on milk agar (Lacey et al., 1970).

\section{Statistical analysis}

Death rates/day (K) were compared by Student's $t$ test.

\section{Results}

\section{Recovery of staphylococci deposited on samples}

All inoculated squares had dried within $24 \mathrm{~h}$. Counts at this time showed that multiplication had taken place. Squares inoculated with $5.0 \times 10^{7}$ staphylococci gave counts of $1.0 \times 10^{8}$ after $24 \mathrm{~h}$; therefore, counts made on day 1 were used as baseline data. No strains showed a fall in count at this time. All counts recorded are the average of quadruplicate $0 \cdot 1-\mathrm{ml}$ samples and, when duplicate textile squares were sampled, there were no significant differences between counts. Strains were tested on two separate occasions and gave reproducible results.

\section{Loss of viability of $M R S A$}

Sixteen MRSA strains were examined. All strains showed loss of viability at day 7 , and their death rates $(K)$ at day 7 , fall into two groups (table I). Strains of phage types $83 \mathrm{~A} / 85 / 95 / 90 / 88$ and $83 \mathrm{~A} /$ $85 / 95 / 88$ had $\mathrm{K}$ values (death rates/day) of $0.09-$ 0.13 with a mean of $0 \cdot 12$; strains of phage types $77 /$ $83 \mathrm{~A} / 84 / 85 / 95 / 90 / 88,77 / 85 / 88$ and $29 / 53 / 85 / 90 / 88$ had $\mathrm{K}$ values of $0.32-0.46 /$ day with a mean of $0.38 /$ day. This difference was statistically significant $(\mathrm{p}<0 \cdot 01)$.

\section{Loss of viability of other staphylococcal strains}

$\mathrm{K}$ values at day 7 of the nine methicillin-sensitive $S$. aureus strains of varying phage types and antibiotic sensitivities were $0 \cdot 07-0 \cdot 22$ /day with a mean of $0 \cdot 12 /$ day (table II). There was no obvious relationship between phage-typing group or antibiotic sensitivity and behaviour on desiccation. Though the strain with the highest death rate, $0 \cdot 22$ / day, belonged to phage group II (type 3C/55/71) and was sensitive to all antibiotics, the other groupII strain (of phage type 71) was resistant to three antibiotics and had a death rate of $0 \cdot 13 /$ day. The 12 coagulase-negative strains identified by API Staph were $10 S$. epidermidis, one $S$. haemolyticus and one $S$. hominis (table III). Their antibioticsensitivity-patterns varied and the range of their $\mathrm{K}$ values at day 7 was wide, $0 \cdot 13-0.52$ with a mean of $0 \cdot 25 /$ day. There was no relationship between resistance to antibiotics and resistance to desiccation in these strains either.

\section{Effect of sunlight on loss of viability of staphylococcal strains}

There was no significant difference between $\mathrm{K}$ values for strains when the textile samples were stored in the dark or in natural light (table IV). The death rates for MRSA strains remained constant over 28 days. Those strains belonging to the local epidemic group showed high $\mathrm{K}$ values at day 7 and continued to do so at day 28 , whereas the death 
Table I. Death rates of methicillin-resistant $S$. aureus

\begin{tabular}{|c|c|c|c|}
\hline $\begin{array}{l}\text { Type of } \\
\text { epidemic } \\
\text { spread }\end{array}$ & $\begin{array}{l}\text { Phage-typing } \\
\text { pattern }\end{array}$ & $\begin{array}{l}\text { Death rate } \\
(\mathrm{K}) \text { at day } 7\end{array}$ & $\begin{array}{c}\text { Mean K } \\
\text { (range) }\end{array}$ \\
\hline General & $\begin{array}{c}83 \mathrm{~A} / 85 / 95 / 90 / 88 \\
", \\
83 \mathrm{~A} / 85 / 95 / 88 \\
, " \\
",\end{array}$ & $\begin{array}{l}0 \cdot 13 \\
0.09 \\
0 \cdot 13 \\
0 \cdot 13 \\
0 \cdot 11 \\
0 \cdot 13 \\
0 \cdot 13\end{array}$ & $\begin{array}{c}0.12^{*} \\
(0.09-0.13)\end{array}$ \\
\hline Local & $\begin{array}{c}77 / 83 \mathrm{~A} / 84 / 85 / 95 / 90 / 88 \\
" \\
" \\
77 / 85 / 88 \\
\text { 29/53/85/90/88 } \\
\text { ", }\end{array}$ & $\begin{array}{l}0 \cdot 39 \\
0 \cdot 46 \\
0 \cdot 42 \\
0 \cdot 41 \\
0 \cdot 32 \\
0 \cdot 42 \\
0 \cdot 36 \\
0 \cdot 34 \\
0 \cdot 32\end{array}$ & $\begin{array}{c}0.38^{*} \\
(0.32-0.46)\end{array}$ \\
\hline
\end{tabular}

Table II. Death rates of methicillin-sensitive $S$. aureus

\begin{tabular}{llcl}
\hline $\begin{array}{l}\text { Phage-typing } \\
\text { pattern }\end{array}$ & $\begin{array}{l}\text { Antibiotic } \\
\text { resistance }\end{array}$ & $\begin{array}{c}\text { Death rate } \\
\text { (K) at day } 7\end{array}$ & $\begin{array}{c}\text { Colour on 40\% milk } \\
\text { agar }\end{array}$ \\
\hline 29 & Pc & $0 \cdot 16$ & Gold-orange \\
$29 / 52 / 80$ & PcTc & $0 \cdot 08$ & $\begin{array}{l}\text { Gold-orange } \\
\text { White }\end{array}$ \\
71 & PcEmTc & $0 \cdot 13$ & White \\
$3 \mathrm{C} / 55 / 71$ & $\mathrm{O}$ & $0 \cdot 22$ & Gold-orange \\
53 & Pc & $0 \cdot 07$ & Gold-orange \\
$53 / 83 \mathrm{~A} / 85 / 90$ & $\mathrm{O}$ & $0 \cdot 07$ & Gold-orange \\
$42 \mathrm{E} / 47 / 53 / 77 / 88$ & Pc & $0 \cdot 10$ & Buff \\
$29 / 52 \mathrm{~A} / 52 \mathrm{~A} / 79 / 80 /$ & & $0 \cdot 08$ & Buff \\
$6 / 47 / 75 / 83 \mathrm{~A} / 85$ & PcEm & $0 \cdot 13$ & \\
96 & Pc & & \\
\hline
\end{tabular}

$\mathrm{O}=$ no resistance $; \mathrm{Pc}=$ penicillin $; \mathrm{Em}=$ erythromycin $; \mathrm{Tc}=$ tetracycline

rates of those strains of the general epidemic group remained lower. However some methicillin-sensitive strains showed higher $\mathrm{K}$ values at day 28 than at day 7, whereas the results obtained with the coagulase-negative strains were varied. The results for three representative strains of CNS are shown in detail. Strain one showed a relatively consistent death rate over 28 days, strain two showed an increase in the rate, whereas the death rate for strain three had decreased at day 28 .

The viability of staphylococcal strains after longer periods of desiccation also varied. Viable cells could be recovered from 5 of the 12 coagulasenegative strains after 12 weeks. Although the $\mathrm{K}$ values for 2 of the 9 methicillin-sensitive strains were low these values did increase with time and no viable cells were recovered from any methicillinsensitive strains after desiccation for 9 weeks. Viable cells were recovered from the MRSA strains belonging to the general epidemic group after 9 weeks but no viable cells from those MRSA strains of the local epidemic group were recovered after 6 weeks.

Pigment production of staphylococcal strains

All seven MRSA strains of phage types $83 \mathrm{~A} / 85$ / $95 / 90 / 88$ and $83 \mathrm{~A} / 85 / 95 / 88$ produced gold-orange 
Table III. Death rates of coagulase-negative staphylococci

\begin{tabular}{llc}
\hline Species & $\begin{array}{c}\text { Antibiotic* } \\
\text { resistance }\end{array}$ & $\begin{array}{c}\text { Death rate } \\
(\mathrm{K}) \text { at day } 7\end{array}$ \\
\hline S. epidermidis & 0 & 0.13 \\
& $\mathrm{Pc}$ & 0.27 \\
& $\mathrm{Pc}$ & 0.19 \\
& Pc & 0.17 \\
& PcTc & 0.29 \\
& PcTc & 0.16 \\
& PcMc & 0.52 \\
& PcTcCm & 0.46 \\
Schaemolyticus & PcMcTc & 0.23 \\
S. hominis & PcMc & 0.13 \\
& PcMcCm & 0.23 \\
& & 0.23 \\
\hline
\end{tabular}

* $\mathrm{O}=$ no $\quad$ resistance; $\quad \mathrm{Pc}=$ penicillin; $\quad \mathrm{Mc}=$ methicillin; $\mathrm{Em}=$ erythromycin $; \mathrm{Tc}=$ tetracycline $; \mathrm{Cm}=$ chloromphenicol.

pigment on milk agar; the remaining nine MRSA strains produced buff-coloured colonies (table V). The pigment production of the methicillin-sensitive strains varied (table II) but the coagulase-negative strains produced no pigment.

\section{Discussion}

The ability of MRSA strains to survive in atmospheric conditions, similar to those found in hospital wards in our climate, varied. Lidwell and Lowbury (1950) showed that there was a correlation between atmospheric humidity and the death rate of bacteria. The temperature and relative humidity during this study showed a range experienced during many months in Sydney.

The interesting observation made from this study of MRSA strains was that strains belonging to those phage types isolated consistently from many hospitals in Sydney and distributed within RPAH showed a low death rate over 28 days, whereas those strains isolated from certain hospitals and from certain wards only within RPAH showed a higher death rate. Variation in resistance to desiccation was also found because viable cells of general epidemic strains were recovered after 9

Table IV. Comparison of $\mathrm{K}$ values of staphylococcal strains over 28 days

\begin{tabular}{|c|c|c|c|c|c|c|c|}
\hline \multirow[b]{2}{*}{ Strain } & \multirow{2}{*}{$\begin{array}{c}\text { Phage-typing } \\
\text { pattern }\end{array}$} & \multirow{2}{*}{$\begin{array}{l}\text { Environmental } \\
\text { condition }\end{array}$} & & \multicolumn{4}{|c|}{ Death rate $(\mathrm{K})$ on day } \\
\hline & & & & 7 & 14 & 21 & 28 \\
\hline \multirow{3}{*}{$\begin{array}{l}\text { MRSA } \\
\text { general epidemic } \\
\text { ( } 7 \text { strains) }\end{array}$} & $83 \mathrm{~A} / 85 / 95 /$ & Dark & & 0.13 & $0 \cdot 16$ & $0 \cdot 15$ & $0 \cdot 17$ \\
\hline & $90 / 88$ & Light & & $0 \cdot 20$ & $0 \cdot 22$ & $0 \cdot 16$ & $0 \cdot 18$ \\
\hline & & & $\begin{array}{l}\text { mean* } \\
\text { range }\end{array}$ & $\begin{array}{c}0 \cdot 12 \\
(0 \cdot 09-0 \cdot 20)\end{array}$ & $\begin{array}{c}0 \cdot 15 \\
(0 \cdot 12-0 \cdot 23)\end{array}$ & $\begin{array}{c}0 \cdot 16 \\
(0 \cdot 11-0 \cdot 23)\end{array}$ & $\begin{array}{c}0 \cdot 14 \\
(0 \cdot 10-0 \cdot 21)\end{array}$ \\
\hline \multirow{6}{*}{$\begin{array}{l}\text { local epidemic } \\
\text { (9 strains) }\end{array}$} & $77 / 83 \mathrm{~A} / 84 / 85 /$ & Dark & & 0.39 & 0.43 & 0.44 & $0 \cdot 30$ \\
\hline & $95 / 90 / 88$ & Light & & $0 \cdot 39$ & $0 \cdot 38$ & $0 \cdot 23$ & $0 \cdot 28$ \\
\hline & & & mean & $0 \cdot 38$ & 0.38 & $0 \cdot 31$ & 0.30 \\
\hline & & & range & $(0 \cdot 32-0.46)$ & $(0.30-0.49)$ & $(0 \cdot 20-0.46)$ & $(0.20-0.43)$ \\
\hline & 29 & Dark & & 0.13 & 0.16 & 0.24 & 0.27 \\
\hline & & Light & & $0 \cdot 15$ & $0 \cdot 18$ & $0 \cdot 19$ & $0 \cdot 24$ \\
\hline \multirow{6}{*}{$\begin{array}{l}\text { Methicillin-sensitive } \\
\text { S. aureus } \\
\text { ( } 9 \text { strains) }\end{array}$} & $3 \mathrm{C} / 55 / 71$ & Dark & & $0 \cdot 22$ & $0 \cdot 21$ & $0 \cdot 22$ & $0 \cdot 22$ \\
\hline & & Light & & $0 \cdot 20$ & $0 \cdot 27$ & $0 \cdot 23$ & $0 \cdot 29$ \\
\hline & 53 & Dark & & $0 \cdot 07$ & $0 \cdot 08$ & 0.09 & $0 \cdot 13$ \\
\hline & & Light & & 0.07 & 0.07 & $0 \cdot 11$ & $0 \cdot 16$ \\
\hline & & & mean & $0 \cdot 12$ & $0 \cdot 12$ & 0.15 & 0.20 \\
\hline & & & range & $(0.07-0.22)$ & $(0.05-0.27)$ & $(0.09-0.25)$ & $(0 \cdot 13-0 \cdot 29)$ \\
\hline \multirow{8}{*}{$\begin{array}{l}\text { Coagulase-negative } \\
\text { staphylococci } \\
\text { (12 strains) }\end{array}$} & NA & Dark & & 0.13 & $0 \cdot 14$ & $0 \cdot 10$ & 0.11 \\
\hline & & Light & & 0.23 & $0 \cdot 19$ & $0 \cdot 17$ & $0 \cdot 13$ \\
\hline & NA & Dark & & 0.04 & $0 \cdot 14$ & $0 \cdot 18$ & $0 \cdot 23$ \\
\hline & & Light & & 0.09 & 0.09 & $0 \cdot 10$ & $0 \cdot 21$ \\
\hline & NA & Dark & & 0.46 & $0 \cdot 23$ & $0 \cdot 17$ & $0 \cdot 21$ \\
\hline & & Light & & 0.42 & $0 \cdot 21$ & $0 \cdot 15$ & $0 \cdot 22$ \\
\hline & & & mean & 0.25 & $0 \cdot 18$ & $0 \cdot 16$ & 0.20 \\
\hline & & & range & $(0.13-0.52)$ & $(0.09-0.26)$ & $(0 \cdot 10-0.28)$ & $(0 \cdot 10-0 \cdot 30)$ \\
\hline
\end{tabular}

* Results for dark and light conditions are included in average $\mathrm{K}$ values and ranges.

$\mathrm{NA}=$ not available. 
Table V. Pigment production of methicillin-resistant $S$. aureus

\begin{tabular}{|c|c|c|c|c|}
\hline $\begin{array}{l}\text { Epidemic } \\
\text { spread }\end{array}$ & $\begin{array}{l}\text { Phage-typing } \\
\text { pattern }\end{array}$ & $\begin{array}{l}\text { Number } \\
\text { of strains }\end{array}$ & $\begin{array}{l}\text { Mean death rate* } \\
(\mathrm{K}) \text { at day } 7\end{array}$ & $\begin{array}{c}\text { Colour on } \\
40 \% \\
\text { milk agar }\end{array}$ \\
\hline General & $\begin{array}{l}83 \mathrm{~A} / 85 / 95 / 90 / 88 \\
83 \mathrm{~A} / 85 / 95 / 88\end{array}$ & 7 & $0 \cdot 12$ & Gold-orange \\
\hline Local & $\begin{array}{l}77 / 83 \mathrm{~A} / 84 / 85 / 95 / 90 / 88 \\
77 / 85 / 88 \\
29 / 53 / 85 / 90 / 88\end{array}$ & 9 & 0.38 & Buff \\
\hline
\end{tabular}

* See table I for range.

weeks of drying, whereas no viable cells of the local epidemic strains were recovered after 6 or 7 weeks.

No difference in survival was observed when MRSA strains and methicillin-sensitive strains were dried on glass (Lacey and Grinsted, 1973) and in our study the death rates of the methicillinsensitive strains at day 7 were low, similar to those of the general epidemic MRSA strains. However, over the longer period of 7 weeks the methicillinsensitive strains did not survive as long as the general epidemic MRSA strains. There was no significant difference between the survival of the local epidemic MRSA strains and that of the coagulase-negative strains at day 7 .

Resistance to drying has been reported to be associated with production of pigment (Grinsted and Lacey, 1973; Gedney and Lacey, 1982) and the present observations support those findings. The MRSA strains most resistant to drying produced a gold-orange pigment; the less resistant strains produced little pigment and were buff-coloured.

\section{REFERENCES}

Bradley J M, Noone P, Townsend D E, Grubb W B 1985 Methicillin-resistant Staphylococcus aureus in a London hospital. Lancet 1 : 1493-1495.

Cafferkey M T, Hone R, Falkiner F R, Keane C T, Pomeroy H 1983 Gentamicin and methicillin-resistant Staphylococcus aureus in Dublin hospitals: clinical and laboratory studies. Journal of Medical Mirrobiology 16: 117-127.

Gedney J, Lacey R W 1982 Properties of methicillin-resistant staphylococci now endemic in Australia. Medical Journal of Australia 1 : 448-450.

Grinsted J, Lacey R W 1973 Ecological and genetic implications of pigmentation in Staphylococcus aureus. Journal of General Microbiology 75 : 259-267.

Lacey R W, Alder V G, Gillespie W A 1970 The survival of Staphylococcus aureus on human skin: an investigation using mixed cultures. British Journal of Experimental Pathology 51 : 305-313.

Lacey R W, Grinsted J 1973 Genetic analysis of methicillinresistant strains of Staphylococcus aureus; evidence for their evolution from a single clone. Journal of Medical Microbiology 6: $511-526$.
This correlation was not as clearly defined with the methicillin-sensitive strains, although the strain with the highest death rate was non-pigmented and sensitive to all antibiotics.

Some correlation between resistance to drying and involvement of staphylococcal strains in epidemics was observed by Rountree (1963) who suggested that the ability to survive for long periods on textiles could be an advantage in the hospital environment. This study shows that some MRSA strains do have a greater ability to withstand drying and this may confer on them a selective advantage over strains that die more quickly. This may explain the variation in epidemiological spread of MRSA stains which we have observed over the last 7 years at RPAH and other Sydney hospitals.

We thank Dr Phyllis Rountree and Professor Yvonne Cossart for their invaluable advice, continuing interest and encouragement, Theresa Rice for technical assistance, and Toni Cozens for her assistance in the preparation of the manuscript.
Lidwell O M, Lowbury E J 1950 The survival of bacteria in dust. II. The effect of atmospheric humidity on the survival of bacteria in dust. Journal of Hygiene 57: 21-27.

McDonald M, Hurse A, Sim K N 1981 Methicillin-resistant Staphylococcus aureus bacteraemia. Medical Journal of Australia 2: 191-194.

Rountree P M 1963 The effect of desiccation on the viability of Staphylococcus aureus. Journal of Hygiene 61 : 265-272.

Schaefler S et al. 1981 Emergence of gentamicin-resistant and methicillin-resistant Staphylococcus aureus strains in New York city hospitals. Journal of Clinical Microbiology 13: 754-759.

Vickery A M, Beard-Pegler M A 1986 Experimental phages assist strain identification of methicillin-resistant Staphylococcus aureus. Abstracts of the XIV International Congress of Microbiology : 272.

Vickery A M, Beard-Pegler M A, Rountree P M 1983 Strain differentiation in methicillin-resistant Staphylococcus aureus. Pathology 15 : 235-240.

Vickery A M, Beard-Pegler M A, Stubbs E 1986 Phage-typing patterns and lysogenicity of methicillin-resistant strains of Staphylococcus aureus from Sydney, Australia, 1965-85. Journal of Medical Microbiology 22: 209-216. 